9. Florensky, P. (2000) Studies on the theory of art // Florensky P., priest. Articles and studies on the history and philosophy of art and archeology. M: Thought [in Russian].

10. Florensky, P. (2004) Philosophy of Cult. M.: Thought [in Russian].

11. Cherednichenko, T. (2002) Musical reserve. 70s Problems. Portraits. Cases M.: New Literary Review [in Russian].

Стаття надійция до редакції 14.06.2017

УДК 78.03+781.6/781.7 DOI: 10.31723/2524-0447-2017-25-167-176

Надія Богданівна Брояко

https://orcid.org/0000-0001-9109-1734

кандидат мистецтвознавства, професор кафедри музичного мистецтва

Київського національного університету культури і мистецтв nbroiako@gmail.com

Вероніка Юріївна Дорофєєва

https://orcid.org/0000-0001-5720-2998

кандидат мистецтвознавства, доцент кафедри музичного мистецтва

Київського національного університету культури і мистецтв knukim_music@ukr.net

\title{
ПРОБЛЕМА ВТІЛЕННЯ ТРАДИЦІЙ УКРАЇНСЬКОГО НАЦІОНАЛЬНОГО МЕЛОСУ У КОМПОЗИТОРСЬКІЙ ТВОРЧОСТІ ДРУГОЇ ПОЛОВИНИ ХХ ст.
}

\begin{abstract}
Метою статті є виявлення провідних аспектів та головних засад втілення українського національного мелосу у композиторській творчості останніх десятиліть. Методологічною основою статті є застосування системного аналітичного підходу з виділенням музикознавчого історичного, текстологічного, комунікативного та семантичного підходів, що дозволяє виокремити провідні риси застосування фольклорноі народно-пісенної спадщини у творчості вітчизняних композиторів другоі половини ХХ століття. Науковою новизною статті є усвідомлення традицій українського національного мелосу як важливої та необхідної складової прояву національної ідентичності у творчості вітчизняних композиторів. Висновки. Багато сучасних вітчизняних композиторів у своїх творах звертаються до головних першоджерел національної культури та переосмислюють на новому рівні виразові можливості народного мелосу. Більшість сучасних композиторів по-новому осмислюе сенс категорії на-
\end{abstract}

(C) Брояко Н. Б., Дорофєєва В. Ю., 2017 
ціонального, звертаючись до вічних першоджерел, до архаїчних пісенних традицій свого народу. Тому можна без перебільщення говорити про те, що неофольклоризм виявився одним з провідних напрямків розвитку української національної композиторської школи, яка, незважаючи на міцну опору на традиції народного мелосу, не заважає при цьому сміливим експериментам та модерністським тенденціям у композиторський творчості. Застосування фольклорних джерел як головного підгрунтя стає новим рівнем опанування архаїчної музичної культури та відкриттям нових можливостей для розвитку традиційного мелосу на сучасному етапі.

Ключові слова: національний мелос, національна традиційна культура, фольклор, неофольклоризм, національні форми мислення.

Broyako Nadezhda Bogdanovna, Ph.D. in Art History, Professor of the Department of Musical Art of Kiev National University of Culture and Arts

Dorofeeva Veronika Yuryevna, Ph.D. in Art History, Associate Professor of the Department of Musical Art of Kiev National University of Culture and Arts

The problem of embodying the traditions of the Ukrainian national melos in the compositional creative of the second half of the twentieth century

The purpose of this article. The main principles and provisions of composer creations are presented in recent decades. Methodological justification of current article is to apply system-analytical approach to the selection of musical-historical, textual, communicative and semantic approaches, which allow to identify the main features of the use folkloric folk-song heritage in creations of the national composers of the second half of the the twentieth century. century. The scientific novelty of this article is the awareness of the traditions of Ukrainian folk composers. Conclusions. All contemporary national composers are appeal to folk cultures and rethink opportunities expressions of folk melos at a new level in their works. Modern composers are comprehend the essence of the category of the national in a new way, referring to the ever-original sources, to the archaic song traditions of their people. Therefore, it is necessary that there is no evidence that neo-folklorism was one of the results of the development of the Ukrainian national school of composition that despite the fact that there are no traditions of folk melodies in this area, it does not interfere with this experiment and modernist tendencies in compositional work. The use of folklore sources as a leading foundation becomes a new level of mastering the archaic musical culture and opening new opportunities for the development of traditional melos at the modern stage.

Keywords: national melos, national traditional culture, folklore, neofolklorizm, national forms of thinking. 
Брояко Надежда Богдановна, кандидат искусствоведения, профессор кафедры музыкального искусства Киевского национального университета культуры и искусств

Дорофеева Вероника Юрьевна, кандидат искусствоведения, доцент кафедры музыкального искусства Киевского национального университета культуры и искусств

Проблема воплощения традиций украинского национального мелоса в композиторском творчестве второй половины ХХ в.

Целью статьи является выделение ведущих аспектов и главных принципов воплощения украинского национального мелоса в композиторском творчестве последних десятилетий. Методологической основой статьи является применение системного аналитического подхода с выделением музыковедческого исторического, текстологического, коммуникативного и семантического подходов, которые позволяют выделить основные черты применения фольклорного народно-песенного наследия в творчестве отечественных композиторов второй половины ХХ века. Научная новизна статьи состоит в осознании традиций украинского национального мелоса как важной и необходимой составляющей проявления национальной идентичности в творчестве отечественных композиторов. Выводы. Многие современные отечественные композиторы в своих произведениях обращаются к главным первоисточникам национальной культуры и переосмысливают на новом уровне возможности выражения народного мелоса. Большинство современных композиторов по-новому осмысливает сущность категории национального, обращаясь к вечным первоисточникам, к архачческим песенным традициям своего народа. Поэтому можно без преувеличения говорить о том, что неофольклоризм оказался одним из ведущих направлений развития украинской национальной композиторской школы, что, несмотря на прочную опору на традиции народного мелоса, не мешает при этом смелым экспериментам и модернистским тенденциям в композиторском творчестве. Применение фольклорных источников в качестве главного основания становится новым уровнем освоения архаичной музыкальной культуры и открытием новых возможностей для развития традиционного мелоса на современHом эmane.

Ключевые слова: национальный мелос, национальная традиционная культура, фольклор, неофольклоризм, национальные формы мышления.

Актуальність статті пояснюється тим, що одним з найбільш важливих та актуальних для сучасної музикознавчої думки завдань є виявлення унікальних якостей та характерних рис українського традиційного мелосу у контексті композиторських пошуків другої половини XX століття. Як відомо, мелодика стала первинним, одвічним способом буття музики як головного способу вираження національних 
особливостей музичного мислення та емоційного стану як окремо узятого митця, так і цілої соціальної та історичної спільноти. Але за багатовікову історію музики вона мінялася, набуваючи кожного разу нових рис, що відповідають розумінню музики в кожній з музичних епох. Тому проблема традиційного національного мелосу завжди безпосередньо пов'язана, по-перше, з історичним стилем та авторським композиторським стилем, по-друге, з тією надзвичайно важливою стильовою сферою - національним стилем, де відбувається процес діалогічної взаємодії двох вищеназваних.

Національний стиль є складним системним явищем з розвиненою багатовекторною ієрархічною структурою, та здатністю виступати цілісною системою художнього мислення, що свідчить про постійну діалогічну взаємодію загальнокультурних норм музичної творчості та особливих шляхів, одиничних способів втілення цих норм у національному континуумі. Треба відмітити, що національний стиль дає можливість активно та динамічно розвиватися подальшому художньому перетворенню та трансформуванню своїх ідей та правил, тобто він є відкритою системою, незважаючи на традиційність й зв'язок 3 канонічним мисленням.

Метою статті є виявлення провідних аспектів та головних засад втілення українського національного мелосу у композиторській творчості останніх десятиліть. Методологічною основою статті є застосування системного аналітичного підходу з виділенням музикознавчого історичного, текстологічного, комунікативного та семантичного підходів, що дозволяє виокремити провідні риси застосування фольклорної народно-пісенної спадщини у творчості вітчизняних композиторів другої половини XX століття. Науковою новизною статті є усвідомлення традицій українського національного мелосу як важливої та необхідної складової прояву національної ідентичності у творчості вітчизняних композиторів.

Загальний огляд літератури по проблемі. Проблема національної культури та наукове обговорення категорії національного вже давно й міцно увійшли в музикознавчий дискурс й набули значення обов'язкової підстави при вивченні будь-якої проблеми, бо вивчення взаємодії художнього мислення й національно-культурних уявлень $€$ одним зі шляхів розуміння культурно-історичного процесу. Так, явище стилю епохи, стилю культури, національного стилю займає значне місце у дослідженнях сучасних музикознавців та культурологів, серед найбільш грунтовних та впливових досліджень у цій сфері слід 
назвати праці Б. Асаф’єва, Д. Ліхачова М. Арановського, М. Бахтіна, В. Бобровського, Л. Акопяна, Г. Гачева, І. Котляревського, М. Михайлова, Є. Назайкінського, О. Сохора, С. Тишко, В. Холопової, Т. Чередниченко та багатьох інших.

Викладення основного матеріалу. Творчий процес у цілому, та зокрема композиторська творчість, передбачає наявність усталеної багаторівневої системи, яка включає в себе комплекс естетичних орієнтирів, художніх еталонів, більше того, важливим для будь-якого творчого акту є дотримання певного типу культури (в тому числі і національної). Цілком очевидно, що закономірності особистісного розвитку обумовлені тими потребами та можливостями свідомості людини, які формують іiі ціннісно-смислові орієнтири та індивідуальні форми відтворення дійсності.

У низці гуманітарних досліджень категорія національного міцно пов'язана з дбайливим ставленням до власної традиційної культури та історичного минулого, у тому числі до фольклорних настанов, за допомогою яких формуються національно-стильові настанови. Не випадково М. Бахтін зазначав, що всі фольклорні жанри стають тією основою, яка одна здатна ініціювати потужний розвиток нових жанрів та формування нових напрямків в мистецтві. Автор визначає їх у якості «нових та могутніх засобів олюднення та інтенсифікації рідного простору» і вважає, що разом з фольклорними тенденціями в мистецтво «увірвалася нова, потужна та надзвичайно продуктивна хвиля народно-історичного часу, який мав величезний вплив на розвиток історичного світогляду» $[1,233]$.

М. Бахтін вказує ще на одну надзвичайно важливу властивість фольклору - хронотопічность всіх його образів, бо фольклор «насичує простір часом» та включає в історичний процес - «втягує його в історію» $[1,234]$. Ці ідеї виявляються надзвичайно важливими в контексті нашого дослідження, тому що фольклорні традиції, народна культура і комплекс звичаїв, властивих українській традиційній культурі, мають потужний вплив на формування національного мелосу, який, у свою чергу, стає надзвичайно важливим підгрунтям у формуванні авторського стилю багатьох вітчизняних композиторів XX століття.

Діалектика відносин між різними типами стилеутворення в музиці дозволяє шляхом порівняльного вивчення національних культур виявляти, чому і яким чином в специфічних авторських інтерпретаціях загальнолюдських «вічних» тем проступають риси національно-стильового мислення. 3 іншого боку, вона дозволяє знаходити новий 
смисловий обсяг реалізації національно-стильових якостей музичного мислення при його залученні до універсалій світової культури.

У зв'язку з цим треба вказати, що дослідження національного характеру виявляє його стабільність й нестабільність одночасно, бо в ньому виявляються ті ж самі риси, які ми можемо спостерігати у дослідженні національно-мовних якостей, які, з одного боку, демонструють канонічність та, у той же час, постійно розвиваються й оновлюються. При вивченні системи художніх принципів та прийомів побудови твору виявляються складні взаємини жанрових та стильових установок музичного мистецтва, у зв'язку з чим виникає необхідність роз'яснення їх семантичного призначення. Тому категорія національного стилю виявляється як наслідок співвідношення опозицій національне - інонаціональне, минуле - сучасне, своє - чуже.

В індивідуалізованій композиторській творчості, особливо коли мова йде про вітчизняних митців XX століття, національні форми мислення можуть бути посилені особистісно-авторською семантикою та слугувати провідником загальнозначущих для людської спільноти ідей, тобто не тільки виступати ідеальною метою, а ще й виконувати функцію художнього інструменту. Це стає відкриттям нових смислових можливостей для застосування національно-стильових засобів художньої виразності та підсилює функцію національного мелосу.

Як широко відомо, мелодика як самостійний художній феномен була завжди, але кожна зміна способів їі буття змінювала й самий мелос. Коли йдеться про монодичні епохи, мелодія брала на себе усю відповідальність за музичне висловлювання, тобто одноголосна музика виявлялася самодостатньою; пізніше, коли поліфонічні форми мають широке розповсюдження, мелодика набуває форми множинного та багатоликого існування у розгалуженій багатоголосій тканині; гомофонія виділила одну мелодійну лінію як носія основного сенсу, зосередивши в ній суть музичного висловлювання та прибравши усі інші голоси в гомогенний рівень акомпанементу. Саме тоді, коли народилося гомофонно-гармонійне мислення як спосіб існування музики, мелодія вирвалася на свободу, інтегрувавши в собі як горизонтальні, так і вертикальні сили взаємодії.

Разом з гомофонно-гармонійним стилем сформувалося особливе явище - мелодійна тема, що стала семантичною тезою, розробка якої породила музичний твір. Мелодія набула нового способу існування та стала значною мірою відповідальною за цілий твір. Таким чином, між 
мелодією та твором виникли причинно-наслідкові зв'язки, де мелодійне начало $є$ не лише початковим імпульсом твору, але й його репрезентантом. Цей подвійний ракурс мелодичної теми зумовив не лише семантичну цілісність твору, але й важливість та деяку автономізацію тематичного матеріалу. Тому цілком зрозуміло, що коли у якості головного тематичного матеріалу композитор бере фольклорний тематичний матеріал, головний напрям подальшого розвитку всього твору вже визначений. Семантичне поле твору завжди виявлялося значно ширшим й набагато складнішим семантики теми, але індивідуальний зміст першого неминуче залежав від індивідуального вигляду теми.

Тому для визначення усіх аспектів композиторського задуму дуже важливим $\epsilon$ визначення походження самого фольклорного мелодійного начала та виявлення умов його історичного існування. Зазначимо, що, як відомо, будь-яка фіксація фольклорного пісенного матеріалу пройшла тривалу еволюцію від постановки проблематики народної творчості як складової духовної спадщини українського народу, через фіксацію літературних текстів, академізований нотозапис, докладні розшифрування аудіозаписів, фахові композиторські обробки фольклорного матеріалу зі збереженням етнохарактерних регіонально-специфічних рис першозразка. Народна пісня в усі часи мала не лише художнє, а й громадське значення, функціонуючи як «один з елементів, що об'єднують людей, полегшують їх організацію і спільну діяльність з метою національного відродження» [2, 19]. Вона стала не лише компонентом духовної надбудови, але й засобом виховання, національної самоідентифікації, виконувала конкретні естетичні, розважальні, соціально-комунікативні функції.

Ще одним дуже важливим аспектом вивчення проблеми взаємовпливу національного мелосу та композиторського стилю $є$ той факт, що вітчизняна музична культура як «цілісний духовно-комунікативний феномен веде до засадничих понять традиції та канону в їх аксіологічній спорідненості» $[3,83]$. Як вказує С. Осадча, «у цьому напрямку наукового пізнання головною для розвитку української музичної культури є православна співацька традиція. Це підтверджується зверненням сучасних українських композиторів до канонічних текстів. Саме сьогодні дуже глибоко усвідомлюється, що українська музична мова - як національна - корінням пов'язана з православним співом, як первинною системою культових вокально-хорових жанрів. Цим пояснюється і пріоритетність хорового співу в українській музиці як її національна культурна ознака» [3, 83]. 
В українській музичній культурі «основною передумовою для сприйняття парадигми комунікаційних відносин стає саме церква та релігія, як особливий тип комунікації, який синтезує різні канали передання інформації та різні комунікативні форми. Духовний, гуманістичний код в українській соціокультурній традиції переважає серед аксіологічних орієнтирів української ментальності і відповідає концепції «нового гуманізму», яка наприкінці XX ст. проголосила пріоритет загальнолюдських інтересів та цінностей» [3, 88].

Творче звернення вітчизняних композиторів XX століття до народної музичної творчості вирізняється характерними ознаками, серед яких можна виділити втілення засобами індивідуально-авторської композиторської творчості комплексу компонентів духовного, соціально-психологічного, етнічного та ментального характеру. Спрямованість твору до певної національної семантики впливає на жанрові настанови, змістовні характеристики твору та підпорядковує собі інші його компоненти, а саме художньо-виразні та стилістичні засоби, образну спрямованість. Головним провідником та виразником національної своєрідності в мистецтві виступає, перш за все, зміст. Але для того, щоб виявити, закріпити й передати національний аспект змісту творчості, надзвичайно важливою, а у деяких випадках абсолютно обов'язковою є демонстрація національного спрямування твору.

Звернення до фольклорної тематики у композиторській творчості «радянської доби» (переважно у другій половини ХХ століття) отримало декілька поняттєвих визначень, а саме - фольклорний напрямок, композиторський фольклоризм, або нова фольклорна хвиля - та стає одним з важливих стильових явищ цього періоду. Але звернення сучасних вітчизняних композиторів до фольклорної спадщини, як до основи власної творчості, має декілька дуже важливих властивостей. По-перше, це авторське переосмислення традицій національного мелосу та фактурних прийомів за допомогою сучасних композиторських технік - принципів додекафонного та серійного мислення, сонористичних ефектів й т. ін.; по-друге, у багатьох випадках зразки національного мелосу стають частиною поліфонічної тканини й головним ії тематичним матеріалом.

Ця нефольклорна тенденція у вітчизняній композиторській творчості XX століття звертається до гуцульських, закарпатських, лемківських, карпатських та багатьох інших зразків традиційної української народної вокальної та інструментальної культури. Головними темами стають відтворення елементів календарно-обря- 
дових дійств, звернення до епічних жанрів (зокрема до лірницьких традицій думного епосу) та до інтонаціонно-мелодійних джерел духовно-співацької спадщини (богослужбових піснеспівів, духовних кантів й псальмів й т. ін.). Зазначену тенденцію можна спостерігати у таких українських композиторів як М. Скорик, І. Карабиць, Л. Дичко, Є. Станкович, Л. Грабовський, В. Зубицький, В. Губа й багатьох інших.

Кожен з перелічених композиторів виробляє свій спосіб і свій метод роботи з фольклорним матеріалом: у деяких випадках опрацьовується оригінальний фольклорний матеріал з дбайливим та обережним ставленням до нього; в інших - відтворюється певне стилістичне середовище, яке створює органічну тканину індивідуально-авторського композиторського погляду на певний музично-історичний матеріал та ніби створює найактуальнішими засобами музичної виразності власну народно-пісенну мелодію.

Серед таких композиторів, творам яких судилося посісти унікальне місце у музичній культури XX століття, $є$ М. Скорик, бо велика кількість творів цього композитора стає репрезентантом української національної ідеї у світі. Одним з найбільш показових у цьому сенсі $€$ «Гуцульський триптих», створений композитором за матеріалами його кіномузики до шедевру С. Параджанова «Тіні забутих предків». Як відомо, цей фільм увійшов за світовим рейтингом ЮНЕСКО у першу десятку найзначніших та найвагоміших досягнень світового кінематографа. Музика М. Скорика в цьому кинофільмі відіграє не останню роль, бо саме завдяки унікальній музичній тканині літературний сюжет М. Коцюбинського досягає епічного розмаху та дозволяє на новому рівні осмислити феномен національної культури.

Висновки. Таким чином, твори багатьох сучасних вітчизняних композиторів звертаються до головних першоджерел національної культури та переосмислюють на новому рівні виразові можливості народного мелосу. Більшість сучасних композиторів по-новому осмислює сенс категорії національного, звертаючись до вічних першоджерел, до архаїчних пісенних традицій свого народу. Тому можна без перебільшення стверджувати, що неофольклоризм виявився одним з провідних напрямків розвитку української національної композиторської школи, яка, незважаючи на міцну опору на традиції народного мелосу, не перешкоджає при цьому сміливим експериментам та модерністським тенденціям у композиторський творчості. Застосування фольклорних джерел як головного підгрунтя для творчості стає новим 
рівнем опанування архаїчної музичної культури та відкриттям нових можливостей для розвитку традиційного мелосу на сучасному етапі.

\title{
СПИСОК ЛІТЕРАТУРИ
}

1. Бахтин М. Время и пространство в произведениях Гете. Бахтин М. Эстетика словесного твориества. М.: Искусство, 1979. С. 204-237.

2. Іван Франко про музику / упор. Т. Коноварт. Львів, 2006. 120 с.

3. Осадча С. Художньо-комунікативний аспект православної традиції в українській музичній культурі. Часопис Національної музичної академії ім. П. I. Чайковського. К., 2012. № 1 (14). С. 83-90.

\section{REFERENCES}

1. Bakhtin, M. (1979) Time and space in the works of Goethe // Aesthetics of verbal creativity. M.: Art, 1979. Pp. 204-237. [in Russian]

2. Ivan Franko about music (2006) / Emphasis. T. Konovart. Lviv 2006. 120 p. [in Ukrainian].

3. Osadcha, S. (2012) Artistic and Communicative Aspect of Orthodox Tradition in Ukrainian Music Cultures // Hour Writing of the National Musical Academy, Im. P. I. Tchaikovsky. K., 2012. № 1 (14). Pp. 83-90. [in Ukrainian].

Стаття надійщла до редакції 14.06.2017

УДК $78.03+78.05$

Олександра Валентинівна Федорова

https://orcid.org/0000-0002-6488-869X

здобувач кафедри музики і музичної етнографії

Одеської національної музичної академії

ім. А. В. Нежданової

fedorova_oleksandra@ukr.net

\section{ДО ПИТАННЯ СТАНОВЛЕННЯ КОМУНІКАТИВНО- ПРИКЛАДНОГО ЖАНРУ «КЛАСИЧНА МУЗИКА В СУЧАСНІЙ ОБРОБЦІ І ФУНКЦІОНУВАННЯ АКАДЕМІЧНИХ ТВОРІВ У МАСОВІЙ МУЗИЧНІЙ КУЛЬТУРІ}

\begin{abstract}
Мета роботи. Стаття присвячена огляду сучасного масового музично-комунікативного простору. Розглядаються питання функціонування класичної музики в рамках комунікативно-прикладного жанру «класи$\kappa а$ в сучасній обробці» $і$ сучасних маскультурних напрямків. Обгрунтовується необхідність аналізу існування академічної музики в сучасному трактуванні, оскільки ігнорування цього веде до заперечення сучасної
\end{abstract}

